\title{
PENGEMBANGAN POLA BERPIKIR KRITIS SISWA MELALUI PEMBELAJARAN BAHASA INDONESIA YANG KONSTRUKTIVISTIK DI SMP KOTA TONDANO
}

\author{
Agus Gerrad Senduk \\ Fakultas Bahasa dan Seni Universitas Negeri Manado \\ email: agsenduk@yahoo.com
}

\begin{abstract}
This study aimed to describe a model of the development of the constructivist Indonesian language teaching to optimize students' critical thinking patterns. The study was carried out by the teachers of Junior High Schools in Tondano. The indicators of such teaching were not so apparent (only $28.42 \%$ ) in the teaching and learning process in the classroom. In other words, the constructivist teaching behavior was very poor in relation to the development of the students' critical thinking patterns. The following indicators showed that the constructivist teaching was not implemented yet: (1) the students were not actively involved designing, doing, and assessing the teaching activities in the classroom; (2) they were not motivated to learn from their friends in the classroom through cooperation, team work, or selfreflection; the cooperative activities were not considered as the main stimulus in the learning process; (3) the teaching and learning activities were not related to the real world, world issues or concrete problems around the students' life; (4) the students' various life contexts were not employed and developed and their prior knowledge was not taken into account in the learning process; and (5) the teachers did not act as facilitators in the students' learning activities.
\end{abstract}

Keywords: development model, students' critical thinking patterns, constructivist Indonesian language teaching

\section{PENDAHULUAN}

Dalam periode tiga puluh tahun terakhir ini filsafat konstruktivisme sangat mempengaruhi perkembangan, penelitian, serta praktik di bidang pendidikan di seluruh dunia. Banyak pembaharuan sistem belajar-mengajar serta kurikulum yang didasarkan pada konstruktivisme, yang terutama menekankan peran aktif siswa dalam membentuk atau membangun ilmu pengetahuan.

Metode menerima dan menghafal pelajaran bahasa merupakan tuntutan utama dalam pembelajaran tanpa disertai pengertian dan pemahaman yang membantu pengembangan kreativitas berpikir kritis siswa. Siswa dipaksa un- tuk menghafal dan menerima begitu saja apa yang diberikan oleh guru tanpa disertai oleh sikap dan aksi kritis. Guru menganggap dirinya sebagai gudang ilmu yang siap menyalurkan ilmunya kepada setiap siswa. Konsekuensinya, sikap pasif dan setia mendengar dari siswa selama ini menjadi andalan dalam dunia pendidikan bahasa di negara kita.

Kegiatan belajar bahasa semestinya merupakan kegiatan yang aktif di mana siswa membangun sendiri pengetahuannya (konstruktivistik). Siswa membentuk pengertiannya dan memberi makna pada pengalamannya. Seorang siswa bertanggung jawab atas hasil be- 
lajarnya karena ia sendirilah yang menjalankan proses penalaran dalam bentuk pemaknaan dan aksi. Belajar oleh seorang siswa merupakan suatu proses organik, bukan proses mekanik. Artinya, belajar adalah suatu proses yang hidup, aktif, dan terus-menerus berkembang.

Pembelajaran bahasa dikatakan berhasil dan berkualitas apabila seluruhnya atau sebagian besar siswa terlibat secara aktif baik fisik, mental, maupun sosial dalam proses pembelajaran. Perlu dikembangkan pengalaman belajar bahasa yang kondusif demi terbentuknya manusia yang berkualitas tinggi (academic excellence). Siswa perlu mendapat bimbingan dan pendampingan sampai ia mampu mengembangkan diri sesuai dengan karakternya. Pendampingan yang dimaksud adalah pendampingan yang bersifat dialogis, bukan indoktrinatif. Diharapkan tidak hanya terbentuk pribadi siswa yang memiliki konsep-konsep bahasa tapi lebih daripada itu terbentuk pribadi yang memahami nilai-nilai bahasa dan mewujudkannya dalam sikap, tindakan dan perilaku berbahasa.

Faktor guru tidak bisa tidak harus diterima sebagai subjek yang menentukan keberhasilan implementasi sebuah inovasi pendidikan di lingkungan sekolah. Faktor atau posisi guru sebagai implementor suatu inovasi dipersoalkan karena "walaupun guru mempunyai kekuasaan terbatas, tanpa kekuatan dan partisipasinya tujuan inovasi itu tidak pernah akan tercapai".

Konsep kompetensi yang merupakan esensi dan ciri pokok Kurikulum 2004 (KBK) dan KTSP 2006 menjadi andalan dunia pendidikan dasar dan menengah di negara kita. Dimensi konstruktivistik-kritis dalam pembelajaran merupakan salah satu pilar belajar yang dituntut oleh KBK dan filosofi pembelajaran kontekstual (lihat Permen No. 22 Tahun 2006). Siswa tidak hanya belajar untuk menjadi orang beriman, untuk memahami dan menghayati, untuk hidup bersama dan berguna bagi orang lain, untuk membangun dan menemukan jati diri melalui proses pembelajaran yang aktif, kreatif, efektif, dan menyenangkan (PAKEM), tetapi juga belajar untuk mampu membangun sendiri apa yang dipelajari dalam bahasa (konstruktivistik-kritis).

Salah satu tantangan yang dihadapi guru dalam mengimplementasikan KBK dan Kurikulum Tingkat Satuan Pendidikan (KTSP), yaitu; tantangan di bidang pengelolaan kurikulum, pembelajaran, dan penilaian. Guru yang profesional akan dapat menyelenggarakan proses pembelajaran dan penilaian yang menyenangkan bagi siswa dan guru, sehingga dapat mendorong tumbuhnya sikap kritis dan kreativitas belajar pada diri siswa. Pemilihan model pembelajaran yang tepat akan sangat menentukan minat dan partisipasi siswa dalam pembelajaran. Melalui model pembelajaran yang tepat diharapkan siswa tidak hanya mendapat pengetahuan, namun juga memiliki kesan yang mendalam dan berarti tentang materi pelajaran, sehingga dapat mendorong siswa untuk mengimplementasikan konsep nilai-nilai dalam kehidupan sehari-sehari.

Dalam penerapan KBK dan KTSP, subyek didiklah yang menjadi pusat dari seluruh proses pendidikan. Dengan demikian, KBK harus menonjolkan kompetensi yang sudah muncul/dimiliki secara kuat dalam diri subyek didik agar mencapai kompetensi maksimalnya, dan untuk kompetensi yang belum dimiliki atau kurang diminati haruslah didorong sampai mencapai standar minimalnya (Yulaelawati, 2004).

Dalam penerapan KBK, bakat dan minat setiap subyek didik semakin ditingkatkan dan terfokus. Seiring dengan itu, juga dalam penerapan KBK, subyek didik tidak dipaksakan untuk menge- 
tahui sebanyak mungkin pengetahuan tetapi lebih pada seberapa mendalam pemahaman kritis mereka akan setiap pelajaran yang mereka peroleh. Dengan kata lain, adalah lebih baik mengetahui sedikit tetapi mendalam daripada mengetahui banyak tetapi tidak mendalam.

KBK memandang subyek didik bukanlah kertas kosong yang siap diisi oleh guru, tetapi sebagai pribadi yang mempunyai bakat dan kemampuan. Oleh karena itu, guru hanya bertindak sebagai fasilitator, mediator, motivator, dan pendamping bagi setiap anak didik (Suparno, dkk., 2002). Dalam arti tersebut, anak didik hendaknya diperlakukan sebagai subyek dan bukan obyek dari suatu sistem pendidikan. Mengapa? Karena melalui proses yang panjang, menurut usianya, setiap anak mempunyai pikiran, sikap, aksi, kehendak, dan perasaan yang berbeda satu dengan yang lain. Dalam proses pembelajaran, tingkat perbedaan ini patut mendapat perhatian dari para guru, agar anak didik dapat berkembang sesuai dengan karakter, bakat, dan minatnya.

Oleh karena itu, anak didik perlu mendapat bimbingan dan pendampingan sampai ia mampu mengembangkan diri sesuai dengan karakternya. Pendampingan yang dimaksud adalah pendampingan yang bersifat dialogis, bukan indoktrinatif (Suparno, dkk., 2002). Artinya, pendidik sebagai pendamping dan anak didik sebagai yang didampingi saling menghormati, terbuka, dan saling percaya. Dengan kata lain, pendidik dan anak didik adalah subyek (Suparno, dkk., 2002). Dalam artian itu, pendampingan yang bersifat pribadi dipandang lebih tepat daripada pendampingan yang bersifat klasikal yang hanya melihat anak didik sebagai obyek belaka. "Pendidikan yang benar harus dilaksanakan melalui dialog di mana masing-masing menawarkan apa yang mereka mengerti" (Bernhae Adeney-Risakotta, 2000).

Dalam KBK setiap anak didik diberikan kesempatan untuk membentuk pengetahuannya berdasarkan apa yang ia pelajari, selidiki, alami, dan kerjakan (Suparno, 1997. Guru hanyalah menjadi mediator dan fasilitator. Artinya, guru bukanlah seorang yang mahatahu dan murid bukanlah orang yang belum tahu dan karena itu harus diberitahu. Dalam proses belajar, muridlah yang aktif untuk mencari tahu dan membentuk pengetahuannya sendiri, sedangkan guru membantu agar pencarian itu dapat berjalan baik. Di sini, hubungan antara guru dan murid lebih sebagai mitra sekaligus teman yang bersama-sama membangun pengetahuan.

Ada kecenderungan sekarang ini bahwa siswa belajar hanya menunggu dan menerima keterampilan ilmu yang diperolehnya tanpa berusaha untuk melatih dan mempraktekannya. Metode menerima dan menghafal pelajaran merupakan tuntutan utama dalam pembelajaran tanpa disertai pengertian dan pemahaman yang membantu pengembangan kreativitas berpikir kritis dan bertindak subyek bina. Hal ini mengakibatkan siswa tidak mampu berpikir secara eksploratif yang mengarah pada kreativitas sintesis (Mangunwijaya, 1999). Kenyataan inilah yang selama berabad-abad dipraktekkan dalam dunia pendidikan kita. Guru memposisikan diri sebagai pusat dan pengendali yang menggiring murid atau subjek bina untuk mengikuti aturan secara ketat, padahal sebagaimana diketahui pendidikan tidak hanya menyangkut kecerdasan intelektual (IQ), tetapi harus dikaitkan dengan seluruh aspek kehidupan manusia. Pendidikan dapat berhasil jika dapat diwujudkan dalam masyarakat sebagaimana yang diharapkan. Pendidikan diharapkan bisa mengembangkan kecerdasan jamak untuk membentuk 
manusia sebagai seseorang yang dapat diandalkan dalam keseluruhan hidupnya demi pengembangan dirinya sendiri maupun masyarakat pada umumnya (Sumarsono, 2004).

Sistem pendidikan kita selama ini kurang memberikan ruang gerak bagi perserta didik untuk mengembangkan secara lebih khusus bakat-bakat yang ada dalam diri peserta didik. Konsekuensinya, siswa hanya menjadi orang yang taat pada "perintah" atau "larangan" sehingga pendidikan yang semestinya membebaskan dan mendewasakan ratio siswa, malah menjadi ruang yang mengurung ratio siswa dalam kemapanan-kemapanan teori atau definisi. Subyek didik dipaksa untuk menghafal dan menerima begitu saja apa yang diberikan oleh guru tanpa disertai oleh sikap kritis. Guru menganggap dirinya sebagai gudang ilmu yang siap menyalurkan ilmunya kepada setiap anak didik. Konsekuensinya, sikap pasif dan setia mendengar dari anak didik menjadi andalan dalam dunia pendidikan kita.

Untuk kepentingan penelitian ini, maka peneliti secara purposif mempersoalkan bagaimana model dan konsep pengembangan pelaksanaan pembelajaran bahasa yang konstruktivistik oleh guru-guru yang mengajarkan mata pelajaran bahasa Indonesia di SMP Kota Tondano untuk pemaksimalan sikap kritis siswa dalam berbahasa. Penelitian ini dilakukan dengan tujuan memperoleh gambaran tentang model pengembangan pembelajaran konstruktivistik dalam bahasa Indonesia untuk pemaksimalan sikap dalam berpikir kritis. Penelitian ini bermanfaat dalam arti memberikan bahan informasi, bahan masukan, dan bahan pertimbangan bagi guru bahasa Indonesia, para penentu kebijakan, penulis buku pelajaran, dan para perencana dan peneliti di bidang pengajaran bahasa Indonesia untuk kepentingan pencerdasan siswa (academic excel- lence) dalam berbahasa Indonesia. Hasil penelitian dapat dimanfaatkan sebagai umpan balik untuk penyempurnaan pengelolaan proses belajar-mengajar bahasa Indonesia yang konstruktivistik. Hasil penelitian dapat pula memberikan kontribusi teoretis dan praktis guna pengembangan teori konstruktivistik dalam pembelajaran bahasa Indonesia.

\section{METODE}

Penelitian yang dilakukan berupa penelitian eksploratif yang bersifat deskriptif analitik. Dengan demikian, objeknya terbatas pada guru-guru bidang studi bahasa Indonesia yang mengajar di SMP di Kota Tondano. Penelitian eksploratif bertujuan untuk menjajagi masalah-masalah yang belum pernah diselidiki secara mendalam, menjajagi sesuatu yang belum dikenal atau hanya sedikit dikenal (Nasution, 1982). Penelitian ini dikatakan bersifat deskriptif karena mengemukakan keadaan yang nyata yang terjadi di lapangan.

Tiga tahapan penelitian yang ditempuh adalah: tahap orientasi, tahap eksplorasi, dan tahap member check. Tahap orientasi dilakukan sebagai tahap awal penelitian untuk memperoleh gambaran yang lengkap dan jelas mengenai masalah yang diteliti. Pada tahap eksplorasi, peneliti berusaha mendapatkan data sebanyak mungkin melalui observasi, wawancara, daftar isian/angket, studi dokumentasi, dan informasi lain yang ada kaitannya dengan permasalahan yang menjadi bahan kajian penelitian. Tahap member check dilakukan agar data penelitian lebih dapat dipercaya. Data dan informasi yang ada dituangkan dalam bentuk laporan lapangan per responden dan diserahkan kembali kepada setiap responden untuk dibaca, dinilai kesesuaiannya dengan informasi yang mereka berikan, dan ditandatangani. 
Instrumen penelitian yang digunakan untuk mengumpulkan data yaitu daftar isian/angket, pengamatan/observasi, dan wawancara. Angket/daftar isian digunakan untuk mengumpulkan data tentang identitas guru, latar belakang pendidikan, pengalaman profesional atau keahliannya, dan konsepnya tentang pembelajaran bahasa berdimensi behavioristik. Dalam melakukan pengamatan di kelas, selain menggunakan daftar isian untuk diskor, peneliti menggunakan catatan-catatan lapangan untuk mencatat hal-hal yang mungkin tidak terliput dalam daftar isian. Dalam melakukan wawancara, instrumen utama adalah peneliti sendiri. Data yang dikumpulkan tidak dibatasi pada satu orang guru, satu kelas atau satu pokok bahasan saja. Wawancara dilakukan untuk memverifikasi data yang dikemukakan dalam angket.

Pengamatan dilakukan peneliti untuk setiap guru bahasa Indonesia yang mengajar di kelas I, II, dan III. Pengamatan dilakukan pada bulan Agustus s.d. Oktober 2008 ketika proses belajar mengajar sedang berlangsung. Daftar isian/angket dan pelaksanaan wawancara dilaksanakan ketika guru-guru tidak sedang mengajar dalam kelas. Kegiatan mengisi daftar isian/angket dan pelaksanaan wawancara dilakukan di luar jam pelajaran.

Penelitian ini difokuskan pada model pengembangan pelaksanaan pembelajaran bahasa Indonesia berdimensi konstruktivistik oleh guru-guru di SMP Kota Tondano. Jumlah sample seluruhnya adalah lima orang guru bahasa Indonesia. Dua orang guru bahasa Indonesia di SMP Negeri 1 Tondano dan masing-masing 1 orang guru bahasa Indonesia di SMP Negeri 2 dan 3 Tondano serta SMP Katolik Rosa de Lima Tondano. Penentuan banyaknya sample bergantung pada taraf redundansi pe- merolehan data yang diperlukan. Sampel bersifat purposif, artinya spesifik sesuai dengan judgement peneliti. SMP yang diteliti adalah SMP Negeri 1, 2, dan 3 Tondano, dan SMP Katolik Rosa de Lima Tondano.

Daftar isian/angket didistribusikan kepada para guru yang diteliti untuk diisi. Data ini diperlukan untuk keperluan analisis komparasi model konsep pengembangan pembelajaran bahasa berdimensi konstruktivistik dilihat dari jenis sekolah, jenis kelamin, masa kerja, dan latar belakang pendidikan. Wawancara dilaksanakan berdasarkan pedoman yang sudah disiapkan terlebih dahulu. Pada dasarnya pedoman wawancara berisi butir-butir pertanyaan yang berhubungan dengan konsep pembelajaran bahasa berdimensi konstruktivistik, model pengembangan pembelajarannya di kelas, dan pengembangan bahan pembelajaran berdimensi konstruktivistik. Guna memudahkan pelaksanaan pengamatan di kelas, setiap indikator yang diteliti dituangkan dalam lembaran pengamatan yang sudah disiapkan terlebih dahulu.

Sesuai dengan sifatnya sebagai suatu penelitian deskriptif analitik, maka teknik persentase digunakan untuk mengolah dan menganalisis data. Informasi yang diperoleh melalui pengamatan di kelas dihubungkan dengan data yang diperoleh melalui daftar isian/angket dan wawancara. Analisis hubungan dan sintesis antara data dalam catatan lapangan, data observasi/ pengamatan, data wawancara, dokumen, dan data yang diperoleh melalui daftar isian/angket dikaitkan dengan teori-teori yang dikemukakan dalam studi kepustakaan yang dilakukan. Dari analisis dan sintesis ini kemudian ditarik kesimpulan, dibahas, diaplikasikan, dan dirumuskanlah saran-saran yang dapat dikemukakan. 


\section{HASIL DAN PEMBAHASAN}

Dari lima (5) orang guru yang diwawancarai, diperoleh informasi bahwa pengajaran bahasa Indonesia (PBI) lebih menekankan keterampilan berbahasa. Intinya adalah penggunaan bahasa Indonesia yang baik dan benar sesuai dengan kaidah-kaidah penentu dalam berkomunikasi. PBI bertujuan mengembangkan kemampuan siswa berbuat sesuatu dengan bahasa yang dipelajari. PBI dilaksanakan dalam suatu konteks dengan berbagai macam ragam bahasanya. Bahasa dipandang sebagai suatu bentuk interaksi dan olehnya harus diajarkan dalam suatu konteks tempat terjadinya interaksi sosial.

Buku teks yang digunakan berdasarkan tuntutan kurikulum. KBK 2004 dan KTSP 2006 menggunakan prinsip kesinambungan, keluasan, dan kedalaman materi yang ternyata belum sepenuhnya diwujudkan. Materi bahasa dalam buku-buku teks yang digunakan ternyata belum disusun berdasarkan hasil analisis kebutuhan siswa. Bahan ajar dikembangkan berdasarkan tugas dan bahan ajar yang asli atau nyata.

KBK 2004 dan KTSP 2006 menggunakan prinsip kesinambungan (keberulangan) materi, tetapi makin tinggi tingkatnya makin luas dan mendalam bahannya. Mengenai materi membosankan, persoalannya di sini bagaimana kreativitas guru agar siswa belajar berbahasa dengan bahan-bahan yang tampaknya mudah dan membosankan itu. Materi ajar masih harus dioperasionalkan, diperluas, dan divariasikan menurut semester dan kelas. Ada upaya dan kreativitas guru untuk mencapai tujuan pengajaran bahasa yang optimal. Ada upaya positif guru untuk memperkaya bahan pelajaran yang diajarkan sebab dengan cara demikian guru dapat mengetahui kelebihan dan kelemahan setiap buku teks yang digunakan. Orientasi materi ajar dalam KBK 2004 atau KTSP
2006 bukan pada struktur linguistisnya, tetapi pada latihan fungsi-fungsi bahasa dalam penggunaannya atau fungsi komunikasi bahasa, sesuai dengan konteks atau situasi penggunaannya. Orientasi inilah yang dipegang guru yang mengemukakan pendapat bahwa teori bahasa itu tidak diajarkan. Akan halnya dengan pendapat bahwa teori bahasa sekurang-kurangnya juga diketahui siswa, hal ini tidak sesuai dengan tuntutan kurikulum, tetapi perlu dipertimbangkan juga.

Tujuan PBI sesuai dengan tuntutan KBK 2004 atau KTSP 2006. Tujuan instruksional umum pengajaran bahasa Indonesia ternyata diartikan secara beragam, tetapi keragaman itu tidak menyimpang dari tujuan pengajaran bahasa Indonesia yang sebenarnya. Tujuan PBI selalu tercapai atau diusahakan berhasil karena antusiasme siswa belajar bahasa cukup besar, tetapi masih perlu terus dikembangkan lagi.

Ada peranan primer dan sekunder yang ditampilkan guru dalam PBI di kelas. Peranan primer adalah: (1) sebagai pemberi kemudahan proses komunikasi antara semua yang terlibat di kelas dan antara mereka yang terlibat dengan berbagai kegiatan dan teks, dan (2) sebagai seorang yang terlibat secara mandiri dalam kelompok belajar mengajar. Peranan sekunder adalah: (1) sebagai pengorganisasi sumber belajar dan sebagai sumber belajar itu sendiri, dan (2) sebagai pembimbing dalam langkah-langkah kegiatan belajar mengajar. Guru telah menampilkan peranannya sebagai penganalisis kebutuhan siswa, penyuluh, dan pengelola proses kelompok.

Unsur siswa menempati posisi yang sangat penting dalam PBM bahasa Indonesia. Sentralitas kegiatan kelas lebih banyak terletak pada siswa ketimbang supremasi guru. Siswa aktif dalam merundingkan makna tugas yang diker- 
jakan. Siswa belajar berkomunikasi dengan cara melakukan kegiatan-kegiatan komunikasi. Suasana kelas yang hiduphidup dan umumnya gaduh, kesenangan, kegairahan, kepuasan, ketertarikan siswa belajar bahasa, soal belajar bahasa yang tidak gampang, dan adanya kemampuan siswa yang beragam, merupakan konsekuensi logis dan positif dari peranan siswa sebagai negosiator antara diri pribadi, proses belajar, dan objek belajar.

Guru menggunakan metodemetode yang bervariasi, yaitu: metode ceramah, tanya jawab, pemberian tugas/penugasan, demonstrasi/simulasi, diskusi, latihan, penemuan, dan metode langsung. Metode-metode ini sesuai dengan apa yang digariskan dalam KBK 2004 atau KTSP 2006. Metode-metode tersebut memungkinkan siswa memperoleh kemampuan komunikatif, mengikutsertakan siswa dalam komunikasi, dan menawarkan penggunaan proses komunikatif sebagai tukar informasi, pengenalan makna, dan interaksi. Metode-metode tersebut bersesuaian pula dengan prinsip penyajian contoh penggunaan bahasa Indonesia pada situasi sebenarnya dan latihan penggunaan kalimat secara langsung untuk menanamkan dan mengembangkan kesadaran struktural gramatikal pada siswa.

Media/alat bantu pengajaran belum digunakan secara maksimal dalam PBM bahasa. Ada pula yang jarang menggunakannya atau lain kali digunakan lain kali tidak. Sebagian besar guru melaksanakan evaluasi walaupun ada juga sebagian kecil guru yang tidak selalu melaksanakan evaluasi dengan alasan-alasan yang sebenarnya tidak perlu. Evaluasi yang dilaksanakan berbentuk lisan dan tulisan, pertanyaan lisan atau tulisan, penugasan, demonstrasi, latihan, tanya jawab, atau membuat kalimat-kalimat.
Pada dasarnya prosedur PBM bahasa Indonesia tidak jauh berbeda dengan pengajaran mata pelajaran lainnya. Variasinya terlihat di sana-sini tetapi ciri khusus PBI tetap kelihatan, yaitu kemampuan siswa menggunakan sistem bahasa secara efektif dan tepat.

Berdasarkan pengamatan perilaku mengajar konstruktivistik guru, dapat disimpulkan bahwa indikator-indikator perilaku mengajar konstruktivistik guru yang diperlukan untuk pengembangan pola berpikir kritis siswa, pada umumnya hanya sedikit pemunculannya $(28.42 \%)$ dalam proses belajar mengajar bahasa Indonesia. Artinya, perilaku mengajar konstruktivistik guru bahasa Indonesia dapat dikatakan sangat kurang untuk mengembangkan pola berpikir kritis di kalangan siswa. Dari 19 jenis indikator konstruktivistik yang diteliti, ditemukan bahwa lima (5) indikator pembelajaran konstruktivistik sama sekali tidak muncul dalam proses pembelajaran. Kelima indikator tersebut adalah: (1) Siswa terlibat secara aktif dalam merancang, melakukan dan mengevaluasi kegiatan pembelajaran; (2) Siswa didorong untuk belajar dari siswa yang lain melalui kegiatan belajar dengan kerja sama, kerja tim, dan refleksi diri. Kemampuan kerja sama menjadi dorongan utama dalam belajar; (3) Pembelajaran dihubungkan dengan kegiatan di dunia nyata atau dihubungkan dengan isu yang disimulasikan dan dengan masalah konkret sekitar diri siswa; (4) Pemanfaatan dan pengembangan konteks kehidupan siswa yang sangat variatif dan pengetahuan awal siswa sangat penting untuk dimanfaatkan dalam belajar; dan (5) Guru bertindak sebagai fasilitator dalam pembelajaran siswa.

Indikator konstruktivistik lainnya memang muncul dalam proses pembelajaran tetapi tidak banyak atau hanya sedikit frekuensinya. Indikator- 
indikator pembelajaran konstruktivistik tersebut adalah: (1) Siswa merasakan langsung sejak awal manfaat pembelajaran yang sedang dilaksanakan; (2) Siswa didorong untuk berperan aktif dan bertanggung jawab dalam memonitor dan mengembangkan kemajuan belajar mereka sendiri; (3) Siswa didorong untuk ikut ambil bagian dalam kegiatan di masyarakat; (4) Proses dan hasil pembelajaran siswa dimonitor dan diasses dengan berbagai cara (alternative assessment); (5) Pendapat siswa diberi peluang dan dihargai dalam proses pembelajaran; (6) Guru menggunakan berbagai macam teknik pembelajaran; (7) Lingkungan pembelajaran bersifat dinamis dan menyenangkan; (8) Menekankan tingkat berpikir kognitif yang tinggi dan menenkankan kemampuan penyelesaian masalah; (9) Siswa dan guru didorong untuk secara kreatif melakukan percobaan-percobaan pada teknik pembelajaran baru; (10) Proses pembelajaran dinilai sama pentingnya dengan hasil pembelajaran; (11) Pembelajaran bisa terjadi dalam berbagai setting dan konteks; (12) Ilmu pengetahuan bersifat interdisipliner dan berkembang sampai di luar batas ruang kelas konvensional; (13) Guru menerima peran sebagai pembelajar seperti para siswanya; dan (14) Pembelajaran dalam banyak konteks memungkinkan siswa untuk mentransfer pengetahuannya/untuk mengidentifikasi dan memecahkan masalah-masalah dalam konteks baru.

Bila dikaitkan dengan hasil temuan melalui wawancara, maka ada kesejajaran antara temuan wawancara dan temuan observasi. Pendapat guru bahasa Indonesia tentang apa itu pengajaran bahasa Indonesia, bagaimana buku teks atau bahan ajar yang digunakan, tujuan PBI, peranan guru, peranan siswa dalam PBM, penggunaan metode dan media/alat pembelajaran, dan prosedur pelaksanaan PBM bahasa Indone- sia di kelas yang konstruktivistik, tidak terbukti pelaksanaannya di kelas ketika pengamatan dilakukan. Data pengamatan menunjukkan bahwa perilaku mengajar konstruktivistik guru bahasa Indonesia yang diperlukan untuk pengembangan pola berpikir kritis siswa, hanya muncul sebesar $28.42 \%$ saja.

\section{SIMPULAN}

Indikator-indikator perilaku mengajar konstruktivistik guru SMP di Kota Tondano yang diperlukan untuk pengembangan pola berpikir kritis siswa, pada umumnya hanya sedikit pemunculannya $(28.42 \%)$ dalam proses belajar mengajar bahasa Indonesia. Artinya perilaku mengajar mereka yang konstruktivistik dapat dikatakan sangat kurang untuk mengembangkan pola berpikir kritis di kalangan siswa. Indikator pembelajaran konstruktivistik yang sama sekali tidak muncul dalam proses pembelajaran adalah: (1) Siswa terlibat secara aktif dalam merancang, melakukan dan mengevaluasi kegiatan pembelajaran; (2) Siswa didorong untuk belajar dari siswa yang lain melalui kegiatan belajar dengan kerja sama, kerja tim, dan refleksi diri. Kemampuan kerja sama menjadi dorongan utama dalam belajar; (3) Pembelajaran dihubungkan dengan kegiatan di dunia nyata atau dihubungkan dengan isu yang disimulasikan dan dengan masalah konkret sekitar diri siswa; (4) Pemanfaatan dan pengembangan konteks kehidupan siswa yang sangat variatif dan pengetahuan awal siswa sangat penting untuk dimanfaatkan dalam belajar; dan (5) Guru bertindak sebagai fasilitator dalam pembelajaran siswa.

Indikator konstruktivistik lainnya memang muncul dalam proses pembelajaran tetapi tidak banyak atau hanya sedikitfrekuensinya.Indikator-indikator pembelajaran konstruktivistik tersebut adalah: (1) Siswa merasakan langsung 
sejak awal manfaat pembelajaran yang sedang dilaksanakan; (2) Siswa didorong untuk berperan aktif dan bertanggung jawab dalam memonitor dan mengembangkan kemajuan belajar mereka sendiri; (3) Siswa didorong untuk ikut ambil bagian dalam kegiatan di masyarakat; (4) Proses dan hasil pembelajaran siswa dimonitor dan diasses dengan berbagai cara (alternative assessment); (5) Pendapat siswa diberi peluang dan dihargai dalam proses pembelajaran; (6) Guru menggunakan berbagai macam teknik pembelajaran; (7) Lingkungan pembelajaran bersifat dinamis dan menyenangkan; (8) Menekankan tingkat berpikir kognitif yang tinggi dan menenkankan kemampuan penyelesaian masalah; (9) Siswa dan guru didorong untuk secara kreatif melakukan percobaan-percobaan pada teknik pembelajaran baru; (10) Proses pembelajaran dinilai sama pentingnya dengan hasil pembelajaran; (11) Pembelajaran bisa terjadi dalam berbagai setting dan konteks; (12) Ilmu pengetahuan bersifat interdisipliner dan berkembang sampai di luar batas ruang kelas konvensional; (13) Guru menerima peran sebagai pembelajar seperti para siswanya; dan (14) Pembelajaran dalam banyak konteks memungkinkan siswa untuk mentransfer pengetahuannya/untuk mengidentifikasi dan memecahkan masalah-masalah dalam konteks baru.

Inovasi pembelajaran kontekstual/konstruktivistik yang sudah diterima dan diimplementasikan sekarang ini harus dibudayakan dalam arti mempengaruhi denyut nadi profesional seorang guru. Dengan kata lain, menerima pembelajaran kontekstual/konstruktivistik berarti menerapkannya secara konsisten di kelas. Jangan terjadi bahwa guru hanya tahu tentang kontekstual atau konstruktivistik, tetapi dalam praktiknya di kelas masih saja menggunakan pendekatan tradisional/behavioristik.
Perilaku atau mentalitas guru bahasa Indonesia harus terlebih dahulu diubah kalau kita ingin agar siswa kita belajar bahasa Indonesia dengan baik dan benar. Perilaku mengajar tradisional/behavioristik guru harus ditinggalkan dan beralih ke pendekatan kontekstual/konstruktivistik karena inovasi pembelajaran tidak akan pernah terealisasi kalau guru masih dikungkung oleh perilaku mengajar yang tradisional.

\section{UCAPAN TERIMA KASIH}

Artikel ini diangkat dari laporan hasil penelitian yang dibiayai oleh Dana DIPA Pascasarjana Tahun 2008, sesuai Akat Kerja Sama Pelaksanaan Penelitian Universitas Negeri Manado Nomor: 2341/H41/KU/2008 Tanggal 23 Agustus 2008. Oleh karena itu, ucapan terima kasih disampaikan kepada BPP Penelitian Pascasarjana Universitas Manado yang telah mendanai dan menyelenggarakan seminar hasil penelitian. Selanjutnya ucapan terima kasih disampaikan kepada dua reviewer anonim yang telah membaca, mengoreksi dan memberi masukan terhadap artikel ini.

\section{DAFTAR PUSTAKA}

Bernhae, Adeney-Risakotta. 2000. “Pendidikan Kritis Yang Membebaskan," BASIS 01-02, Tahun ke-50 (Januari-Februari, 2000), hlm. 15.

Departemen Pendidikan Nasional. 2004. Kurikulum Berbasis Kompetensi Mata Pelajaran Bahasa Inggris SMA. Pusat Kurikulum Badan Penelitian dan Pengembangan Departemen Pendidikan Nasional, Direktorat Jenderal Pendidikan Dasar dan Menengah, Jakarta.

Yulaelawati, Ella. 2004. "Pembelajaran Kurikulum 2004," dalam Educare no. 2/1 (Mei 2004), hlm. 19.

Mangunwijaya, Y.B. 1999. Pasca Indonesia-Pasca Einstein. Yogyakarta: Kanisius. 
Nasution, S. 1985. Didaktik Asas-asas Mengajar. Bandung: Penerbit Jemmars.

Sumarsono. 2004. “Tujuan Negara: Mencerdaskan Kehidupan Bangsa" dalam Educare, No. 1/I/April 2004. hal. 33.
Suparno, Paul. 1997. Filsafat Konstruktivisme dalam Pendidikan. Yogyakarta: Kanisius.

Suparno, Paul. dkk. 2002. Reformasi Pendidikan: Sebuah Rekomendasi. Yogyakarta: Kanisius. 